Document downloaded from:

http://hdl.handle.net/10251/122876

This paper must be cited as:

Cerrada-Serra, P.; Colombo, L.; Ortiz-Miranda, D.; Grando, S. (2018). Access to agricultural land in peri-urban spaces: social mobilisation and institutional frameworks in Rome and Valencia. Food Security. 10(6):1325-1336. https://doi.org/10.1007/s12571-018-0854-8

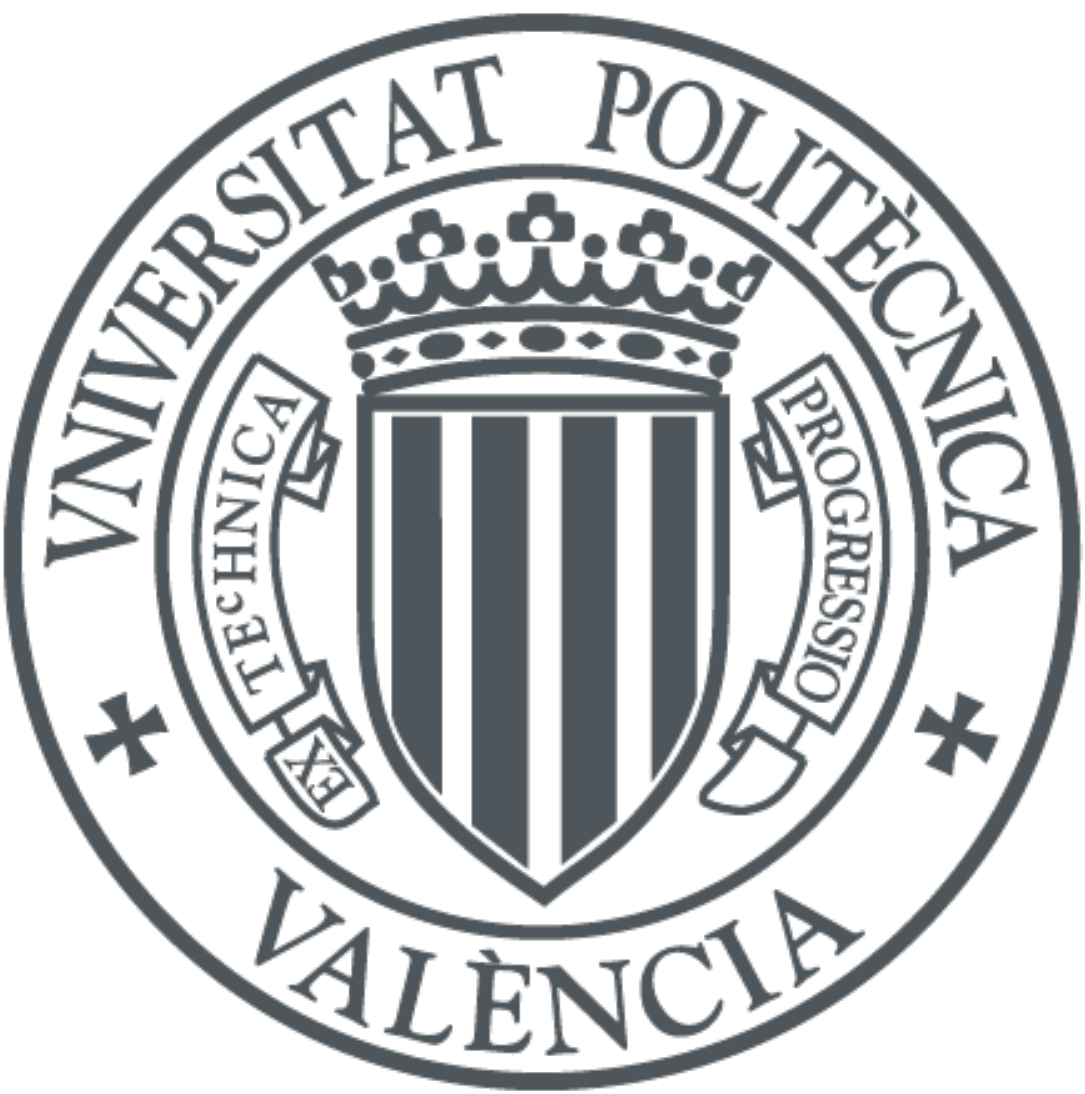

The final publication is available at

https://doi.org/10.1007/s12571-018-0854-8

Copyright Springer-Verlag

Additional Information 


\section{Access to agricultural land in peri-urban spaces: social mobilisation and institutional frameworks in Rome and Valencia ${ }^{1}$}

Camino de Vera s/n

Tlf. (+34) 963877000 Ext. 74722

Luca COLOMBO (l.colombo@firab.it)

Italian Foundation for Research in Organic and Biodynamic Agriculture (Fondazione Italiana per la Ricerca in Agricoltura Biologica e Biodinamica-FIRAB)

Via Pio Molajoni 76

00159 Rome (Italy)

Dionisio ORTIZ-MIRANDA (dortiz@esp.upv.es)

Department of Economics and Social Sciences

Universitat Politècnica de València

Camino de Vera s/n

46022 Valencia (Spain)

Stefano GRANDO (stefano.grando@yahoo.it)

Italian Foundation for Research in Organic and Biodynamic Agriculture (Fondazione Italiana per la

\footnotetext{
${ }^{1}$ Cite as: Cerrada-Serra, P., Colombo, L., Ortiz-Miranda, D., Grando, S. Food Security. (2018). https://doi.org/10.1007/s12571-018-0854-8

${ }^{2}$ Corresponding author
} 
Via Pio Molajoni 76

00159 Rome (Italy)

\section{Introduction}

Urban and peri-urban agriculture (UA and PUA respectively) have gained worldwide momentum within the framework of the renewed food and nutrition security agenda and are receiving greater consideration in their potential role to sustainably provide healthy and nutritious food to a growing urban population (FAO, 2014; Eigenbrod and NazimGruda, 2015). This is so not only in the developing world but also in the global North (Opitz et al., 2016), in which UA could grow the basic vegetable intake of the urban poor (Badami and Ramankutty, 2015) and answer the specific demands for culturally-acceptable food (Wekerle and Classens, 2015), one of the requirements considered in the utilisation dimension in the FAO's definition of food security.

The way in which UA and PUA can reframe urban food and nutrition security (FNS) and reconnect urban centres with their surrounding territories has given rise to the concept of 'city region food systems', defined as "the complex network of actors, processes and relationships to do with food production, processing, marketing, and consumption that exist in a given geographical region that includes a more or less concentrated urban centre and its surrounding peri-urban and rural hinterland; a regional landscape across which flows of people, goods and ecosystem services are managed" 3 .

Although UA and PUA are often considered under the common label of urban agriculture, it has been argued that it is necessary to tackle them separately, as their dynamics and their potential contribution to FNS can completely differ (Opitz et al., 2016). PUA has been said to be a residual form of agriculture at the fringe of growing cities (Opitz et al., 2016): the peri-urban area, characterised by its spatial fuzziness, further complicated by its temporal transitionality and uncertainty (Wästfelt and Zhang, 2016). However, PUA is also a meeting space, reconnecting the urban and the rural, the city and its surroundings (Sonnino, 2007; Päul and McKenzie, 2013). PUA has the potential to provide a number of goods and services to urban dwellers that go beyond food (Zasada, 2011).

The European cities in the Mediterranean Basin have been argued to maintain strong links with their surroundings (Päul and McKenzie, 2013). In a review of the main recent dynamics of periurban agroecosystems, Soulard et al. (2017) find that the urban regions of Southern Europe have witnessed a renewal of the links between urban development and agriculture as a consequence of the recent economic crisis and the mobilisation of urban actors to rebuild the food connections between the city and its surrounding countryside. This indicates that the renewal of PUA and its contribution to FNS form part of a broader process of new food politics and cannot be separated from the role of emerging food-related social movements. This combination of factors -the renewed social and political interest in PUA, the search for new livelihood options in the context of the economic crisis and the opportunities arising from growing market demands for proximity food (Duke and Aull-Hyde, 2002) - has given rise to a growth in PUA initiatives of critical mobilisation, led either by newcomers or by already installed farmers.

\footnotetext{
${ }^{3}$ Definition provided by the City Region Food Systems Alliance in 2015, quoted in Blay-Palmer et al. (2018).
} 
However, these initiatives have to overcome a major limitation in peri-urban spaces: the access to farmland, a key constraint to fully realizing the potential of PUA, which can undermine the capacity to take full advantage of new opportunities in city region food systems (Forster and Getz-Escudero, 2014). The academic literature frequently mentions producers' difficulties in accessing farmland as a characteristic and crucial factor conditioning PUA dynamics and the feasibility of professional, market-oriented food production initiatives. However, a few empirical analyses directly tackle these points. This is so despite the attention that this issue receives in the local urban policy agenda in several places in Europe (see for example Galli et al., 2010; RUAF, 2017), where local and regional authorities try to respond to the growing social demands by exploring mechanisms to 'mobilize' both public and private vacant land in peri-urban areas.

This paper explores how socio-political mobilisations that combine claims for the renewal of local food systems and new models of urban-periurban governance is revitalising the questions of the access to peri-urban farmland. A comparative analysis was conducted in two Mediterranean metropolitan areas (Rome in Italy and Valencia in Spain), where different institutional and policy frameworks shape the conditions for new farmers or already installed farmers to access farmland, in both cases aiming to adopt alternative business models. The two cities were also similarly hit by serious youth unemployment and witnessed recent profound changes in political settings driven by the crisis of traditional parties in both countries, so opening up possible windows for bottom-up initiatives. Furthermore, Rome and Valencia are both engaged -as outstanding signatories of the Milan Urban Food Policy Pact ${ }^{4}$ - in developing local participatory food policies, so that the paper also connects the way social movements activate processes of spatial, material, relational and conceptual reconfiguration in dialectic interaction with local institutions, and so influence the reshaping of food systems.

The paper is structured as follows: the next section synthesises some key points in the literature regarding access to land in PU areas in the global North. Case studies and data collection procedures are then presented. The results are split into two sections: the new momentum of periurban agriculture is described in both metropolitan areas and farmland access mechanism are characterised. The results are then discussed and compared. The paper ends with some concluding remarks.

\section{Literature review: farmland issues in peri-urban areas}

Farmers' access to land has become an outstanding issue in the global FNS agenda, in part due to the role of social movements, which have specifically contributed to calling attention to these issues at local and international levels (Franco et al., 2015), including Europe (Borras et al., 2016).

In the same vein, access to land has also been identified in the Global North as a crucial and constraining factor in the development and transformation of peri-urban agriculture (Lovell, 2010). In a survey conducted in the SUPURBFOOD Project, interviews with public and private experts (Schmid et al. 2015) found that the demand to local governments to protect and enable access to and tenure of land for food production in urban and peri-urban areas ranked first among the demands addressed to local city governments to support innovative SMEs and organizations which deliver multifunctionality through food production in urban food systems.

\footnotetext{
${ }^{4}$ For instance, Valencia was declared the 2017 World Sustainable Food Capital.
} 
Access to land in peri-urban spaces is totally conditioned by the intense competition for land use due to urban growth processes that often take the form of urban sprawl. Indeed, peri-urban spaces are characterised by high land prices (Munton, 2009), so that even prime agricultural land is used for development (Knowd et al., 2006). Wästfelt and Zhang (2016) state that land value anticipation is amplified by urban speculative behaviour, leading to higher rents, shortage of land and fragmentation of land ownership. In order to remain open to future urbanisation opportunities, many public and private land owners often tolerate UA only as an interim use (Opitz et al., 2016). Apart from the high prices and the long term insecurity of tenure rights, peri-urban farmland is affected by land fragmentation due to urban sprawl and infrastructure development.

The market forces operating in peri-urban areas are subjected to strong land use regulation by regional and local public bodies, which, on the other hand are also influenced by these same forces. In fact, one of the aims of these regulations is precisely to protect farmland from urban-related developments. In this regard, zoning regulation -i.e. the definition of zones adjacent to urban areas where land use change is forbidden- has been the traditional tool for farmland protection (Zasada, 2011). Actually, as Opitz et al. (2016) argue, in order to improve the contribution of PUA to urban food security, urban pressure has to be regulated and controlled and priority zones for farming can be an effective planning instrument to provide more security and stability for peri-urban farmers.

However, it has also been argued (Päul and McKenzie, 2013) that effective farmland protection cannot be achieved simply by means of zoning restrictions and it is necessary to sustain the productive dimension of agriculture. Long-term tenancy security thus becomes a crucial factor for farm viability. As Munton argues, land property rights are held in more complex ways (including more short-term letting of land) in the urban fringe. In Southern Europe, Soulard et al. (2017) report cases of occupation of vacant peri-urban plots for farming without the knowledge (or consent) of landowners. The insecurity associated with these situations affects the farms' investment level and survival strategies (Peron and Geoffriau, 2007; Piorr et al. 2011). Interestingly, it has been found that in some cases farmers use private land with the permission of landowners, which leads to a relationship based on personal relationships dependent on trust and shared values and interests (Wekerle and Classens, 2015).

In short, peri-urban areas are a fuzzy meeting space of different land uses and related interests. This makes PUA an arena of social and political struggle in which interests and values converge and collide. Besides, this takes place in a context of fragmented governance, both multiscale -as land use politics are shaped at different levels (local, regional, national, European), and multi-territorial as many land planning responsibilities in PU areas are in the hands of different municipalities that compete with each other to attract new facilities and infrastructures (Allen 2003).

\section{Case studies and data collection}

Rome and Valencia are both large metropolitan areas, with more than 4 million inhabitants in Rome and $1.7 \mathrm{~m}$ in Valencia. Both cities share the features of other large western urban centres with regard to competition for land use, building sector relevance and influence and city expansion.

In the case of Rome, large portions of arable land are still available, even in public hands, in areas often characterised by environmental and social vulnerabilities. In recent years this has led to social mobilisation aimed at obtaining access to farmland units for young farmers. This initiative obtained some success (two tenders and first assignments) and was also a cradle for social innovation whose potential and ambition goes beyond the creation of new peri-urban farms. The agricultural landscape is characterised by arable crops, olive groves, horticulture and permanent grass for sheep 
and cattle husbandry, mainly managed by professional farmers, coexisting with a proliferation of urban gardens.

One of the distinguishing features of Valencia's peri-urban agriculture is the large irrigated agricultural area around the city, known as the Huerta of Valencia, which is considered the most important of the few remaining agricultural systems of its type in Europe (European Environmental Agency, 1995). Its production system consists of intensive horticulture and permanent crops. This unique, and at the same time fragile environment, has traditionally supplied fresh food to the city, besides also being an important area of commercial agriculture. However, several converging processes now threaten its future and have reduced the supply of arable land. While large portions of PU areas are held by public institutions in Rome, in Valencia this type of land is mostly privately owned, and the supply of farmland is made up of plots that are abandoned, sold or rented out by retired farmers.

Despite the differences, both cases have common factors. First, there is renewed interest by young people in developing peri-urban agricultural initiatives, motivated by new food business opportunities in response to the growing interest of urban consumers in local organically-grown food and the proliferation of local alternative food networks. Although they include different profiles, their promoters share some common features: they are looking for new forms of proximity and direct selling pathways to urban consumers and claim to adopt agroecological farming methods. Secondly, these initiatives are socially and politically embedded within broader social movements engaged in food sovereignty discourses and peri-urban space protection. Many of these food producers are active in the leadership of these movements. Thirdly, farming in PUA appears as a viable source of income and an unemployment response for young urban dwellers. Finally, these factors (growing economic demand and social movements' activism) have led local authorities supporting these initiatives, in particular regarding access to land.

Data collection in both cases was guided by the need to harvest first-hand information through a participative approach capable of grasping the key elements of processes largely based on grassroots initiatives and social engagement. Beyond the initial desk analyses, interviews with stakeholders and experts and personal participation in events and initiatives (sit-in, public debates, and open seminars) were at the core of the process. A peculiar element of this common approach was a two-session scenario workshop in each case study of the TRANSMANGO project, following shared guidelines developed by a project partner with solid expertise in the field (Vervoort et al. 2016).

Informants in both case studies had different profiles: (i) farmers developing new production initiatives and aspiring young ecological farmers; (ii) managers of food business initiatives (e.g. selling platforms); (iii) representatives, members and activists of social organisations engaged in alternative food networks and the protection of peri-urban high value areas, environmentalists; (iv) consumers engaged in alternative food networks (CSA, box schemes, direct purchase); and (v) staff from local and regional public bodies in charge of institutional mechanisms to access land; experts from universities (social sciences, agronomists).

Several secondary sources were consulted in a desk-based analysis to obtain a wider picture of the analysed topics and to better frame the information acquired from primary sources. These include scientific and grey literature on the subject, internal social organisation documents, policy documents, press releases of public bodies and media articles. This work led to a preliminary assessment of the most relevant aspects of each case together with a historical insight into recent events that led to the current situation.

A set of semi-structured interviews was then carried out between November 2015 and June 2016 to collect the opinions of stakeholders and experts to acquire an understanding of the different 
positions, objectives and visions of the reference groups. In Valencia 22 interviews were conducted with key actors from different backgrounds: 9 local producers, 5 with representatives of public bodies, 4 from the consumer context, 2 social organizations and 2 professional experts. The interviewees were initially selected on the basis of our knowledge of the case study, followed by snowball sampling from an expert-driven selection and direct contacts with farmers and producers. A similar process was followed in Rome, where 14 exploratory semi-structured interviews were conducted with producers and aspiring farmers, representatives of public bodies, technicians, NGOs and farmers' leaders to complete this step of the research.

Participatory observation was also widely used. In Valencia, we attended a series of talks related to this research and we also participated in several initiatives conducted by social movements in collaboration with the Valencia city council, on sustainable food and peri-urban agriculture. Two local farmers' markets were also visited and we spent several working days on a small producer's farm. In Rome meetings and flash-mobs organised by land access activists were attended, as well as a series of seminars organised, again by a group of activists, to offer aspiring farmers information on legal requirements, financial tools and technical advice on land access and peri-urban agriculture. Participatory observation in Rome started even before the case study research period, as part of an activity of constant interaction with land-related processes. This activity provided useful insights into mobilisation dynamics and guidance for the fieldwork.

Two-session participatory scenario workshops were organized, reflecting the common methodology adopted for the project case-studies. The workshops combined retrospective analysis (backcasting) and narrative of exploratory scenario techniques. The workshops were also meant to provide a space for open debate and suggestions for individuals and organizations involved and/or interested in the initiatives. The aim was to encourage the different actors to interact and exchange ideas on present and plausible future scenarios and challenges, detached from day-to-day pressures and duties. In Valencia, two workshop sessions were organised (in March and May 2016) with the participation of 23 and 19 people respectively. In Rome, 15 people attended the workshops (held in February and April 2016).

A final comment needs to be made regarding the type of informants in this research. In spite of having very different profiles -and often very different views on a range of issues, almost all the interviewed actors were in favour of protecting PUA and setting up renewed food ties between periurban producers and the city. However there are other actors who can influence the becoming of peri-urban spaces (property owners, investors, building companies, land developers, or large conventional farmers), who probably have different perspectives. These actors were not directly interviewed, as our focus was on social mobilisation and understanding the extent to which the new ways to access peri-urban land enable the development of new agricultural initiatives. This is not to say these conventional actors are irrelevant in this process, for instance, they may have a role in accelerating, distorting or blocking legal reforms, but their information would have been more relevant if our study had included an in-depth analysis of the processes of institutional change, which was not the case.

\section{A new momentum for peri-urban agriculture in Rome and Valencia}

\section{Public land for young farmers in Rome}

Rome is characterised by the coexistence of built-up and green areas, not only in the outskirts but even close to the city centre. Green areas are sometimes utilised as gardens or leisure spaces, but more often tend to be abandoned or used as rubbish dumps. In the peri-urban areas suitable for 
agriculture, farming has often to compete with other uses with strong economic and/or social pressures (housing, shopping malls, transport infrastructures), usually exercised by the powerful building sector. However, this complex and contradictory urbanization process leaves large nonbuilt-up spaces, providing a great potential for the use of these public assets for a more effective (agricultural) land management. This has been considered as a potential for local food system diversification and, not least, for creating job opportunities for the young unemployed.

Starting in the late '90s, the Rome Administration launched the 1966 Municipal Master Plan revision process, stressing their intention to preserve farming land in the largest agricultural municipality in Italy. Economic and political struggles took place over the various options, particularly over the "compensation planning system", first introduced in 1997, which rules that the construction of new buildings or infrastructures can be controlled by the local council in environmentally sensitive areas. When this happens, the company is allowed to build elsewhere, but only if the bonded area is handed over for free to the local authority. In 2003 a new Master Plan was adopted and finally approved in $2008^{5}$. About 700 hectares of potentially available public land suitable for agriculture in Rome became available due to these "compensations". Part of the land involved in these compensation measures became the object of social movements aimed at triggering land assignations.

On the basis of these policy developments, various other grassroots initiatives have also recently been instigated to grant young would-be farmers easier access to unused or inappropriately used portions of land and give them the opportunity to become farmers.

Among these, the Coordination for Access to Land (CRAT in Italian), a network set up by a group of young (existing and would-be) farmers, consisting of various farmers' and non-farmers' organizations and potential beneficiaries, was particularly active in organizing a mobilization based on flash-mobs, symbolic occupation of abandoned areas, public meetings, educational seminars and participation in third party conferences. The catalyst for the CRAT movement was a declaration of intent called "Vertenza" (literally "dispute"). This 4-page document aimed at getting the local administrations to discuss and solve the problem of the adequate development of public land suitable for agriculture in Rome (CRAT, 2011). The "Vertenza" described the Roman countryside as characterised by biodiversity, wetlands and hills, historical heritage and modern infrastructures, underlining the pivotal role that agriculture could play in its safeguard and ecologically-sound development. The document expressed the need for clear and transparent procedures for assigning public land to young farmers, with the aim of recovering abandoned or under-utilised plots of land while establishing a new alliance between urban farmers and consumers. As direct interactions with local authorities and policy makers was deemed crucial for the strategy, meetings were organised with the head of the Regional Agency for the Development and Innovation of Lazio Agriculture (ARSIAL), with municipal and provincial council members and with the mayor of Rome. The role of some well-established cooperative farms, some of which originated from land occupation in the 70's, was important to provide initial suggestions and guidance, also for the existing working and training collaboration between some of the young activists and these cooperatives.

This mobilisation was one of the levers that led to the publication of two tenders for access to public land for agricultural use in Rome and surrounding areas, which is analysed below.

\section{Farmland protection in the Huerta of Valencia}

The agri-food industry is a significant sector of the whole Valencia region, which has a longstanding agricultural tradition and the city has been historically closely bound up with its singular peri-urban Huerta. This man-made landscape, of high agricultural, environmental and cultural

\footnotetext{
${ }^{5}$ Rome City Council Decision n.22, 12/02/2008.
} 
value, has been wisely shaped through the centuries and constitutes the matrix that, in a total area of 23,000 hectares, brings together 44 municipalities and about 12.000 ha of smallholders' farms that can provide up to three crops per year. The network of irrigation channels and ditches, built during the Moorish period, is a key structural element in this landscape.

In the last decades the Huerta has experienced drastic transformations as never before, and several processes threaten its continuity. Together with the abandonment of agricultural land - low economic and social recognition threatens generational renewal-, the area has experienced strong pressure from urban sprawl, infrastructures and communications networks, which has led to a loss of productive capacity and spatial fragmentation. In 55 years, the Huerta area has been reduced by $38 \%$, from about 19,500 ha in 1956 to 12,200 ha in 2011 . The area dedicated to producing fruit and vegetables has been reduced by $64 \%$ in this period (Soriano, 2015). According to PATODHV 6 , the degradation of the area is aggravated by problems in the irrigation infrastructure and water pollution, visual fragmentation and deterioration, and fewer farms, due to lack of generational renewal.

However, the last 15-20 years have witnessed two processes. On the one hand, the city and surrounding municipalities have seen the emergence of a strong social mobilisation in defence of this agricultural space, mostly around the association "Per L'Horta". As Gómez Ferri (2004) explains, the germ of this association dates back to 2001 when a Popular Legislative Initiative $(\mathrm{PLI})^{7}$ was promoted by the "Plataforma per un Cinturó d'Horta" (Platform for a Huerta Belt) to declare the remnants of Valencia's Huerta as a protected natural area. "Per L'Horta” was precisely the campaign's slogan, in which around 100 different groups and associations from the whole Valencia region were involved, mainly environmental groups, trade unions, neighbourhood, student and cultural associations, also some political parties. Paradoxically, the presence of farmers' associations was minimal, as a majority of farmers (who were also landowners) considered the PLI as a potential threat to their expectations regarding urban sprawl and land revaluation. Although the campaign collected more than 100,000 signatures (doubling the 50,000 signatures required for its parliamentary process), the Valencia Regional Parliament voted against taking the PLI into consideration. Nevertheless, the campaign succeeded in mobilizing an important part of society, generating debate and public awareness. "Per L'Horta" became the heir to the first initiative, which today continues to work for the protection and enhancement of the Huerta de Valencia.

On the other hand, the city has witnessed the proliferation of several food-related initiatives (CSA groups, box schemes, revival of some farmers' markets, and grocery and web platform initiatives to promote local fruit and vegetables). This has meant both a social revaluation of peri-urban agriculture and the emergence of new food-related business opportunities. New young organic/agroecological farmers are trying to reconnect with urban consumers and re-establishing production-consumption proximity relations, while some already installed farmers also adopted organic farming and started to explore short food supply chains (SFSC).

\footnotetext{
${ }^{6}$ The Plan de Acción Territorial de Ordenación y Dinamización de la Huerta de Valencia (Territorial Action Plan of Management and Revitalization of the Huerta of Valencia) is a long-awaited comprehensive action plan for territorial planning at metropolitan level in the Huerta area. It has received a new impetus and currently is being developed by the regional government.

${ }^{7}$ Popular Legislative Initiatives are meant to be a procedure of participatory democracy, a mechanism for direct involvement by citizens in policy-making, although it hardly ever leads to the adoption of an act. In the Valencia Regional Parliament at least 50,000 signatures are required to start the process.
} 
These two processes have been parallel and interwoven. Some of these farmers (despite being a minority) rapidly became leaders of the movement for the protection of the Huerta. In this social movement, farmers play a fundamental role in maintaining the agricultural activity necessary to preserve the territory and avoid its becoming a 'museum'. For this, it is necessary to guarantee both the profitability of agricultural activity and effective protection of the territory (through land use planning regulations).

All these actors -who had adopted a defensive profile against the regional and local administrations- witnessed how the municipal and regional elections of 2015 gave way to a new government much closer to their position of protecting the Huerta. This has led to new policy of initiatives designed to create better conditions for peri-urban farmers and other local food actors.

\section{Different modalities and institutional frameworks to access peri-urban}

\section{farmland}

As stated above, peri-urban farmland in both Rome and Valencia has been under considerable pressure due to urban sprawl in the last decades. This is so despite the supposedly rigid and longterm regulatory regime. Indeed, zoning regulations determining peri-urban land uses and land development potentials are defined in municipal master plans: the Piano RegolatoreGenerale (PRG, from 2008) in Rome and the Plan General de Ordenación Urbana (PGOU from 1988) in Valencia. These are long-term land use plans from 1966 in both cases. This makes evident, as Zasada (2011) points out, how large-scale public planning is not capable of addressing small-scale functional changes that together are able to transform the agricultural landscape.

The private supply of farmland has been strongly conditioned by the land development expectations of landowners, which confirms the point made by Opitz et al. (2016) regarding the interim features of PUA. In Rome, the so-called 'agricoltura di attesa' (which could be translated as 'waiting agriculture'), voids farming business plans, as the landowners act as rentiers waiting for those areas to become suitable for urbanisation. The capacity of the regional and municipal administrations to find land available for farming, environmental and social functions has generally been limited by the persistence of illegal land occupation and the difficulty of obtaining an equitable acknowledgement of informal rights (Gallico \& Groppo, 2015). In Valencia, the several abandoned plots (due to farmers' retirement and the low profitability of small-scale conventional farming) are rarely sold or legally rented (which requires minimum periods of renting), as sometimes landowners (and their heirs) expect the future revaluation of the land.

Yet, some residual land tenure dynamics remain in both PU areas, which maintain relevant farming potential making them attractive for new entrepreneurial initiatives. The two cases under analysis illustrate different modalities to access farmland.

In Italy, two recent national Decrees ${ }^{8}$ gave public authorities owning arable and agricultural land the permission to assign allotments to young would-be farmers with the aim of "giving new life to state-owned land suitable for agriculture, transforming them into a job opportunity for the new generations"9. Nevertheless, the rationale of the acts -as witnessed by the role played by the Ministry of Economy and Finance (MEF), is less oriented towards land access policies than towards

\footnotetext{
${ }^{8}$ The Decree on Liberalizations (DL, Decretolegge 24/01/2012, n. 1) and the Decree "Terre vive" (living lands), approved in 2014.

${ }^{9}$ Extracted from http://www.agenziademanio.it/opencms/it/terrevive/. Accessed July 2017.
} 
harvesting financial resources to reduce the public deficit, as two farmer-activists reported during the research interviews.

In any case, at local level, this new regulatory framework, together with the pressure exerted by the Coordination for Access to Land, gave rise in 2014 to the publication of two tenders for the agricultural use of public land in the land around Rome: one promoted by ARSIAL, the other directly by the Rome City Council.

- The ARSIAL-Regional tender. The first tender was issued by the ARSIAL in February 2014. It had two main objectives: enhancing access for young farmers to agricultural land and protecting the quality of the land owned by the Region while using it for economic and social purposes (Gallico \& Groppo, 2015). A total of 320 hectares for the main part in the province of Rome (290 ha) and in the province of Viterbo (30 ha) were made available to farmers for 15 (renewable) years alongside overall financial resources of $€ 650,000$.

- The Municipal tender. The second tender was issued in May 2014, with four allotments to be assigned in the municipal territory. The tender was meant to be the first step of a wider policy of land distribution whose header "Roma, città da coltivare" (Rome, a city to cultivate) expresses the idea that taking care of Rome also means promoting agriculture and farming. The size of the four areas identified for the assignments ranged from 14 to 33 hectares, with a total of 97 hectares. A rural building was available for use (at least partially) by the assignment holders in all of them.

In both cases, the criteria for selecting farmers in the tenders reflected some of the ideas promoted by the social movements, for example with regard to the priority for young farmers (maximum 40 years old) and 'green' production methods. In the municipal tender, bids were evaluated against seven parameters, ranging from the applicant's agricultural competence to the robustness of his/her proposal and the foreseen use of renewable energy. The seven conditions also included the adoption of organic farming methods, which was one of the highest-rated parameters, scoring 15/100 points. The four selected proposals were finally chosen out of a group of 104 , of which $80 \%$ were submitted by young farmers and $34 \%$ by women: all the assignees had presented business plans grounded on organic farming.

The Vertenza stated "We imagine the Agro Romano and the urban agricultural land being managed with the creativity, the vitality [...] the enthusiasm and the openness to the future of the young agricultural entrepreneurs". Ten individual young farmers and cooperatives set up new farms. In most cases, the new farmers aimed at establishing short chains and direct contact with consumers in a social business perspective and at relying upon organic production methods as a condition for sustainability and as a marketing lever. As stated by one interviewed activist (a young female farmer, who had not taken part in either tender), "the engagement point was no longer the mere access to land, but food policies centred on local food systems and food sovereignty”.

Part of the public land available for tenders was provided by private companies as a consequence of the implementation of the already mentioned "compensation planning system", which brought new environmentally sensitive areas under the management of the Municipality.

The situation is different in Valencia, where land property is mainly private, so the access mechanisms mostly depend on private agreements and initiatives. Different modalities were identified in the interviews: 
- In some cases, new entrants to farming accounted for family land. It is not infrequent in metropolitan Valencia that -particularly elder people- still own plots of land in the surroundings. This has allowed younger generations to start farming activity using these plots, as well as the associated assets (equipment, practical knowledge, networks).

- Those without land need to resort to tenancy agreements with landowners. There is still some land available, though in the form of small scattered plots owned by retired farmers or their heirs ${ }^{10}$. However, renting is expensive, particularly close to the urban fringe, as was learned from one of the interviewees, a young already installed farmer recalling his initial stages: "I was sharing a rented plot with a friend in Picanya $[7 \mathrm{Km}$ from Valencia city centre] (...). It was a disaster (...) the cost of the land was very high, about three times the price of the best field you can find in Lliria [nearly $30 \mathrm{Km}$ from Valencia city centre]". In addition, new farmers complain that many landowners are reluctant to formalise renting contracts $^{11}$. Another young organic producer interviewed estimated that 9 out of 10 renting contracts were informal. Landowners' distrust of newcomers (especially those adopting 'alternative' production methods) and the possibility of taking advantage of potential revaluation options explain their reluctance to formalise tenancy agreements. As a matter of fact, this informality could also benefit producers (by avoiding taxation). However, informality is detrimental for medium-term crop planning, investments in irrigation infrastructures or initiating the conversion process to organic farming for certification purposes.

- Municipal authorities are also trying to mediate between owners of vacant farmland and those willing to initiate or expand their farming activity. In some cases, municipal authorities (e.g. in Pobla de Vallbona, within the Huerta) took the initiative of allowing the occupation of plots of land owned by banks or other private actors, who had not initiated the process of urbanisation. In other cases, municipalities try to mediate by creating land banks. Under this modality, landowners can offer their plots to be included in a municipal register that is offered to farmers looking for new land. The municipality aims to reduce transaction costs and to give security to the parties (particularly landowners). However, although some land banks have been formally created, they are not yet effective, as a young would-be farmer complained. Two interviewees, from the administration and university, argued that many owners are reluctant to cede their land to these intermediate entities and distrust the new farmer to whom it is granted. Furthermore, there is no inventory of abandoned plots, which would allow the local administration to act in specific cases. In addition, some land banks cover several municipalities (e.g. the Pactem Nord Consorcio). The potential advantage of a larger scale operation collides with coordination problems between different municipal administrations. "It is a supra-municipal institution, which complicates the process” (agricultural administration expert).

\footnotetext{
${ }^{10}$ The drop in the price of citrus fruits -one of the main crop in the study area- also contributed to farmers leaving the land.

${ }^{11}$ Formal contracts are regulated under the Agricultural Renting Law that stipulates minimum contract periods and a number of guarantees for tenants.
} 


\section{Rome and Valencia}

The comparison of two case studies conducted in Rome and Valencia highlights some common elements that deserve attention.

First, both cases are the expression of the new and growing opportunities that are emerging for local organic food producers, in a framework of transition (at least for certain segments of the population) towards alternative and differentiated food system configurations. This shapes a new and potentially enabling setting for want-to-be or already installed farmers. Nevertheless, new agricultural ventures are severely constrained by the difficulties of access to land in these peri-urban contexts, where urban development (buildings, transport infrastructures, space-demanding manufacturing or commercial sites, leisure spaces, etc.) complicates the access to an appropriate farmland base (high land prices and market rigidity, fragmented plots, long term tenancy insecurity, basic infrastructure availability).

Access to land is closely interrelated with access to other productive assets. For instance, in Rome some new farmers had organisational and technical problems due to the poor state of the soil (following decades of abandonment or illegal use), unsuitable irrigation infrastructures, and even the impossibility of using rural buildings, as foreseen in the assignment contract, due to delays in the refurbishment of the structures. These barriers were raised by the assignees during the scenario workshops, when they called for licences from the administration for refurbishment and full operationalisation of the areas. Access to credit also becomes a problem, as new farmers may have no collateral or do not comply with the criteria to be granted public rural development aids for the setting up of agricultural activities. Informal land tenancy agreements also hamper funding possibilities. In Valencia, access to water is also an additional constraint (high price of groundwater, or inability to adapt to the communal rules governing water use).

Second, in both case studies, the fieldwork found that the new entrants' motivations and profiles, their choice regarding farming and business models, the modalities of access to land and the institutional responses, are part of a broader framework of social and political mobilisation revolving around food system models and urban development. In other words, access to peri-urban land for food production cannot be dissociated from the socio-political transformative aim of the actors involved. The active role played by civil organisations in Rome (e.g. CRAT) and Valencia (e.g. Perl'Horta) has been crucial in forming a favourable social climate for these initiatives and an enabling institutional framework. For this aim, these actors have argued their legitimacy (e.g. heritage and environmental protection, youth employment or participatory governance), and have claimed supportive political agendas, which, as the interviewees acknowledge, are highly dependent on the changing political contexts and on the personal commitments of policy makers and local authorities, who are only in office for a limited period.

The political dimension of these networks and actors is also linked to the search for a different city model, urban planning, and urban-peri urban relationships. It is also related to the defence of the Huerta's historical and cultural heritage, somehow paralleled by the 'campagna romana' (roman countryside) environmental, landscape and historic relevance. For these organisations, alternative local food systems are instrumental in achieving this aim. In other words, the protection of the PU areas could not be achieved simply by means of traditional land use regulations (zoning and restrictions), but requires the active presence of a population of professional farmers with viable businesses. 
Table 1 summarises and compares the main features of the two case studies and shows how, despite the differences regarding land access mechanisms, they are just two pieces of a single story. The similarities of farmers' motivations and the business models they aim to adopt, the constraints they confront, the way they are committed and engaged in larger socio-political movements aspiring to food system transition, are all expressions of individual and collective initiatives that are taking place in many peri-urban areas in Europe and beyond. Local and regional administrations seem to be adopting (at least in the two case studies) a supportive approach to these individual and collective claims. Yet, facilitating access to farmland to give rise to new modes of city region food systems constitutes a totally new and complex issue, which clashes with the inertia of administrative structures and traditional modes of policy intervention.

Table 1. Common features of access to farmland in peri-urban Rome and Valencia

\begin{tabular}{|c|c|c|}
\hline & Rome & Valencia \\
\hline Land ownership & Public & Private \\
\hline Access mechanisms & Public allotments & $\begin{array}{l}\text { Access to family farmland, land } \\
\text { renting (with or without a formal } \\
\text { contract) and municipal land banks }\end{array}$ \\
\hline Tenancy security & High (15 year-contracts) & $\begin{array}{l}\text { From high (family land) to low (non- } \\
\text { registered renting, occupation) }\end{array}$ \\
\hline Newcomers' motivations & $\begin{array}{l}\text { Employment and eco-social } \\
\text { business }\end{array}$ & $\begin{array}{l}\text { Employment and ideology } \\
\text { motivations (e.g. agroecological } \\
\text { commitment) }\end{array}$ \\
\hline $\begin{array}{l}\text { Farmers' entrepreneurial } \\
\text { models }\end{array}$ & Individual / Cooperatives & Individual \\
\hline Productive orientation & Organic vegetables & Organic vegetables \\
\hline Marketing practices & SFSC & $\begin{array}{l}\text { SFSC, though some are accessing } \\
\text { export niche markets }\end{array}$ \\
\hline Lacking or limited assets & $\begin{array}{l}\text { Knowledge/Training } \\
\text { Machinery } \\
\text { Financial credit } \\
\end{array}$ & $\begin{array}{l}\text { Knowledge/Training } \\
\text { Machinery } \\
\text { Financial credit } \\
\end{array}$ \\
\hline $\begin{array}{l}\text { Farmers' political } \\
\text { engagement }\end{array}$ & $\begin{array}{l}\text { Land \& food sovereignty } \\
\text { movements }\end{array}$ & $\begin{array}{l}\text { Huerta heritage protection and } \\
\text { agroecological and food sovereignty } \\
\text { movements }\end{array}$ \\
\hline Socio-political legitimacy & $\begin{array}{l}\text { Landscape safeguard } \\
\text { Fresh food delivery } \\
\text { Public land management in times of } \\
\text { budget constraints } \\
\text { Youth employment } \\
\text { Neighbourhood encouragement }\end{array}$ & $\begin{array}{l}\text { Landscape and heritage safeguard } \\
\text { Environmental-friendly production } \\
\text { methods } \\
\text { Youth employment }\end{array}$ \\
\hline $\begin{array}{l}\text { Local Administrations' } \\
\text { attitude }\end{array}$ & Erratic, but generally supportive & $\begin{array}{l}\text { More supportive since last local and } \\
\text { regional elections, but too soon to } \\
\text { assess real impact }\end{array}$ \\
\hline
\end{tabular}

Source: Authors' elaboration.

\section{Conclusions}

The outcomes of the parallel research activities and the subsequent reflections suggest some conclusive remarks as regards future opportunities and critical issues for the development of a rich and diverse PUA supported by clear and democratic procedures for land access. 
The cases of Rome and Valencia provide different entry points to the common issues of land access, as in the first case we deal with public land, whereas private land is at stake in the second. However, the role of public bodies is crucial in both cases. Similarly, the activists' ability to promote and discuss their visions and interests with local authorities is a key factor for the success of the land access and PUA initiatives, yet still on a limited scale.

Indeed, political will or ability to support the agricultural use of land is crucial to overcome the strong competition from non-agricultural uses, both when land is in public and private hands. The low priority given in the past to land access and PUA by local administrators, fragmentation of competences and interventions, dependence on changing political conditions and personal commitments, and speculative private interests are among the main critical issues in this regard. How to make more farmland available - and successfully cultivable - for new/aspiring farmers? If in public hands, a public interest vision accompanied by full identification of the available allotments and the design of tenders by clear and democratic procedures is recommended. If in private hands, the administration could help overcome the reluctance of ownership in the formalization of contracts and to mediate in disputes, and increase taxation on idle lands to penalize their owners. Moreover, in both cases the needs and abilities of small/young players beyond land access should trigger public supportive initiatives if an economically and socially sustainable UPA is to be developed, e.g. training, access to credit, and facilitating direct selling.

However, focusing on land access transparency and democracy is not enough: as argued by Franco et al (2015) democratic control of farming land (and land in general) cannot be politically separated from the broader idea of an alternative (food) system. This is clear from the initiatives and the vision of activists in both cases. Perspectives like food sovereignty, agroecology and sustainable food chains are present as elements in a desired future, but also as mobilisation catalysts and communication levers. As stated in the Roman Vertenza, small farms play a key role in safeguarding the territory re-launching local markets, with the creation of short food supply chains and the revaluation of local agro-biodiversity (Vertenza, p.2; CRAT, 2011). Democratic access to land is key factor in these processes. In this respect, "land access back in the policy agenda remains a political success (...) for a movement looking for the social function of land to be guaranteed", as emerged in an interview with one farmer activist (a young woman who did not take part in land assignations, but confirmed the political importance of the movement). This means that the success of these initiatives is linked to their ability to trigger processes of food system rebuilding at the local (urban and peri-urban) level. These processes entail new configurations, or new assemblages, of spaces, actors and resources, requiring critical bottom-up mobilisation on one side, but also adequate governance and institutional support on the other.

Indeed, some areas for improvement in this regard can be identified on the political side. A need arises to improve horizontal and vertical coordination at municipal and regional levels to achieve common strategies for all issues related to urban agriculture, food policy, land planning, public health and social welfare. In Rome and Valencia these fields are currently covered by different governing bodies inefficiently communicating with each other. Developing metropolitan planning and legal instruments is essential (especially important in Valencia where there are over 40 different municipalities within the Huerta area).

Food and land-related activists aspire to becoming the necessary partners of local administrators willing to promote a more sustainable and socially valuable use of peri-urban land in times of public budget constraints. Conflicts certainly arose when strategic decisions, such as those related to the 
use of a scarce resource like land, are at stake. However, these are stratified levels of conflicts, with contrasts at a certain level but also re-composition at other levels. Even the building sector could profit, for example, from the presence of better managed green spaces and by the availability of social and ecological services offered by peri-urban farms, which could make peri-urban areas more attractive to new dwellers.

The claim for responsible land tenure regulations and practices can be an element of a wider transition towards more democratic and sustainable local food systems, as well as an ideological glue for activists and other committed stakeholders. Shared endeavours, even from different individual points of view, and collective engagement are key to overcoming the limits imposed by the small scale of most of the actors in terms of lobbying capacity, ability to gain public attention and, last but not least, ability to meet the increasing consumer demand.

The more successful these pioneer initiatives are, the more diffuse small and medium urban and peri-urban farms will become, with the possibility of operating as outposts of activism scattered throughout the peri-urban territory. If this happens, these farms could create a sort of "neural network" (a metaphor suggested in the Roman scenario workshop) able to connect different initiatives and promote new relations between urban dwellers and the peri-urban countryside. Upon these new cross-boundary relations connecting market and society, communities and nature, food and land issues, food systems could be, at least partially, rebuilt towards more differentiated and sustainable configurations. In this respect, social movements around food and agriculture, particularly when matched by a positive predisposition of the administration, can act as catalysers for a more profound reordering of priorities, power relations, business opportunities and practices.

The comparative reading of the research findings in the areas of Rome and Valencia highlights the importance of land access for the development of initiatives capable of triggering this transformation of the food systems. Adequate rules and governance capable of identifying and encouraging seeds of change and innovative practices can transform this potential bottleneck into a lever of systemic transition and rebuilding.

\section{Acknowledgments}

This research is part of the project "Assessment of the impact of global drivers of change on Europe's food security” (TRANSMANGO), granted by the EU under 7th Framework Programme; theme KBBE.2013.2.5-01; Grant agreement no: 613532.

\section{Conflict of Interest}

The authors declare that they have no conflict of interest.

\section{References}

Allen, A. (2003). Environmental planning and management of the periurban interface: Perspectives on an emerging field. Environment and Urbanization, 15(1), 135-148.

Badami, M. G., \&Ramankutty, N. (2015). Urban agriculture and food security: A critique based on an assessment of urban land constraints. Global food security, 4, 8-15.

Blay-Palmer, A., Santini, G., Dubbeling, M., Renting, H., Taguchi, M., \& Giordano, T. (2018). Validating the City Region Food System Approach: Enacting Inclusive, Transformational City Region Food Systems, Sustainability, 10(5), 1680. 
Borras, S.M, jr., Seufert, P, Backes, S, Fyfe, D, Herre, R, Michele, L, \& Mills, E. (2016). Land Grabbing and Human Rights: the Involvement of European Corporate and Financial Entities in Land Grabbing outside the European Union. European Union, Policy Department, DirectorateGeneral for External Policies. doi:10.2861/26

CRAT (2011). Vertenza per la salvaguardia dell'Agro Romano - Terre pubbliche ai giovani agricoltori. http://www.aiab.it/images/stories/UfficioStampa/vertenzagroromano.pdf. Accessed July 2017.

European Environmental Agency (1995). Europe's Environment - The Dobris Assessment. Copenhagen.

Duke, J. \&Aull-Hyde, R. (2002). Identifying public preferences for land preservation using the analytic hierarchy process. Ecological Economics, 42, 131-145.

Eigenbrod, C., \&Gruda, N. (2015). Urban vegetable for food security in cities. A review. Agronomy for Sustainable Development, 35(2), 483-498.

FAO (2014). Growing greener cities in Latin America and the Caribbean. A FAO report on urban and peri-urban agriculture in the region. Rome.

Forster, T. \& Getz-Escudero A (2014). City Regions as Landscapes for People, Food and Nature. EcoAgriculture Partners, on behalf of the Landscapes for People, Food and Nature Initiative. Washington, DC

Franco, J., Monsalve, S. \&Borras, S. (2015). Democratic land control and human rights, Current Opinion in Environmental Sustainability, 15, 66-71.

Galli, M., Lardon, S., Marraccini, E., \& Bonari, E. (Eds.) (2010). Agricultural management in periurban areas. FeliciEditore. Ghezzano, Italy.

Gallico, L. \&Groppo, P. (2015). VGGT as a Tool for Improving Access to Land and the Responsible Management of Natural Resources: Based on the Experience of Lazio Region and Rome Municipality. FAO - Land and Water Division (NRL), Rome.

Gómez Ferri, J. (2005). Los movimientos ciudadanos de defensa y activación del patrimonio en Valencia: los casos del barrio del Cabanyal y la ILP per l'Horta. In Coordinadora de defensa del Rincón-Ecologistas en Acción. Experiencias sociales innovadoras y participativas. El Rincón + 10. (pp. 157-205).

Knowd, I., Mason, D., \& Docking, A. (2006). Urban agriculture: the new frontier. Changing City Structures, 23.

Lovell, S.T. (2010). Multifunctional Urban Agriculture for Sustainable Land Use Planning in the United States. Sustainability, 2, 2499-2522.

Munton, R. (2009) Rural land ownership in the United Kingdom: changing patterns and future possibilities for land use. Land Use Policy, 26, S54-S61.

Opitz, I., Berges, R., Piorr, A., \&Krikser, T. (2016). Contributing to food security in urban areas: differences between urban agriculture and peri-urban agriculture in the Global North. Agriculture and Human Values, 33(2), 341-358.

Paül, V. \& McKenzie, F.H. (2013). Peri-urban farmland conservation and development of alternative food networks: Insights from a case-study area in metropolitan Barcelona (Catalonia, Spain). Land Use Policy, 30(1), 94-105.

Péron, J.Y., \&Geoffriau. E. (2007). Characteristics and sustainable development of peri-urban vegetable production in Europe. ActaHorticulturae, 762, 159-170.

Piorr, A., Ravetz, J. \&Tosics I. (Eds.) (2011). Peri-urbanisation in Europe: Towards European policies to sustain urban-rural futures. Copenhagen: University of Copenhagen, Forest and Landscape. 
RUAF (2017). European case studies on governance of territorial food systems - project GouTer. https://www.ruaf.org/sites/default/files/European\%20case\%20studies\%20on\%20governance\%20 of\%20territorial\%20food\%20systems\%20Gouter-RUAF\%20final.pdf

Schmid, O., Moschitz, H., Dubbeling, M., Fritschi, R., Jahrl, I. \&Wiskerke, H. (2015). Governance for urban food systems - Recommendations from SUPURBFOOD project. http://archive.harperadams.ac.uk/events/ifsa-conference/papers/5/5.6\%20Schmid.pdf. Accessed July 2017.

Sonnino, R. (2009). Quality food, public procurement, and sustainable development: the school meal revolution in Rome. Environment and Planning A, 41, 425-440.

Soriano, V. (2015). La huerta de Valencia un paisaje menguante. Amazon.

Soulard, C. T., Valette, E., Perrin, C., Abrantes, P. C., Anthopoulou, T., Benjaballah, O. et al. (2017). Peri-urban agro-ecosystems in the Mediterranean: diversity, dynamics, and drivers. Regional Environmental Change, 1-12.

Vervoort, J.,Helfgott, A. \& Lord, S. (2016) TRANSMANGO Deliverable 3.2: Scenarios Methodology Framework and Training Guide.

Wästfelt, A. \& Zhang, Q. (2016). Reclaiming localisation for revitalising agriculture: A case study of peri-urban agricultural change in Gothenburg, Sweden. Journal of Rural Studies, 47, 172-185.

Wekerle, G. R. \&Classens, M. (2015). Food production in the city: (re) negotiating land, food and property. Local Environment, 20(10), 1175-1193.

Zasada, I. (2011). Multifunctional peri-urban agriculture-A review of societal demands and the provision of goods and services by farming. Land use policy, 28(4), 639-648. 